\title{
2009 METŲ EUROPOS PARLAMENTO \\ RINKIMŲ LIETUVOJE REZULTATAI: APLINKYBĖS IR PROGNOZE்
}

\section{Mindaugas KLUONIS}

Vilniaus universiteto Tarptautiniu santykiu ir politikos moksly institutas The Institute of International Relations and Political Science of Vilnius University

Vokiečiug. 10, LT-01130 Vilnius

El.paštasmkluonis@yahoo.com

\section{Santrauka}

Straipsnyje analizuojami 2009 m. rinkimu i Europos Parlamenta rezultatai, ju ¿taka Lietuvos partinès sistemos raidai, aptariamos menko rinkejju dalyvavimo priežastys. Taip pat apžvelgiamas Lietuvos politiniu partiju priklausymo Europos Parlamento grupems pagristumas ir ideologinis adekvatumas.

Straipsnyje remiamasi Maiklo Maršo (Michael Marsh) pateiktomis hipotezemis apie dalyvavima Europos Parlamento (toliau - EP) rinkimuose, taip pat autoriaus atliktais tyrimais. Daroma išvada, kad 2009 m. EP rinkimu rezultatai Lietuvoje atskleidžia didejančiq politine partiju poliarizacija, tačiau atitinka klasikiní antraeiliu rinkimu apibrèžimq ir neleidžia daryti išvados apie skeptiška Lietuvos rinkèju požiūrì z Europos Sajungq.

Reikšminiai žodžiai: Europos Parlamentas; antraeiliai rinkimai; euroskeptiškumas; partinè sistema; politinė poliarizacija; partijų institucionalizacija.

\section{Ivadas}

Lietuvoje vykusių rinkimų i EP rezultatai yra palyginti mažai analizuoti tiek europinès, tiek vietinès politikos tyrimuose. Tokị menką dèmesi jiems gali lemti tai, kad šie rinkimai yra gana naujas reiškinys - Lietuvoje jie vyko tik $2004 \mathrm{~m}$. ir 2009 m. Be to, rinkimų i EP rezultatų analizę ir lyginimą apsunkina tai, kad 
2004-aisiais jie sutapo su Respublikos Prezidento rinkimu pirmuoju turu. Dèl gausaus dalyvavimo (palyginti su europinio pobūdžio rinkimais) 2004 metais ir skirtingos situacijos (artejusių Seimo rinkimų) gali būti sunkiau palyginami ir rinkimų rezultatai, nors esminès tendencijos išliko tos pačios.

Šio straipsnio tikslas - aptarti 2009 m. Lietuvoje vykusių rinkimu i EP rezultatus pagal tris klausimu grupes.

Pirmojoje dalyje aptariamos dalyvavimo EP rinkimuose palyginimo problemos ir analizuojama, kiek pagrịsti teiginiai, kad dalyvavimas buvo išskirtinis.

Antroji dalis skirta aptarti rinkimų i EP įtaką Lietuvos partinès sistemos raidai ir, remiantis rinkimų rezultatais, pateikti galimas šios raidos prognozes Europos Sajungos politikos kontekste. Straipsnyje didžiausias dèmesys skiriamas euroskeptinei nišai ir keliama hipotezè, kad ši niša Lietuvoje jau užimta partijos „Tvarka ir teisingumas“ (toliau - TiT), todèl kitu partijų, išskyrus Tèvynès sajungą-Lietuvos krikščionis demokratus (toliau - TS-LKD), euroskeptinè politika Lietuvoje neturi perspektyvų.

Trečioji dalis skirta aptarti Lietuvos politikų dalyvavimo EP politinėse grupėse ir ju jungimosi prie vienos ar kitos grupés pagristumą, remiantis EP grupių ir Lietuvos partijų propaguojamų idejjų santykiu ir partiniu stabilumu EP.

Analizės metodas: aprašomasis-analitinis, remiamasi politikų atsakymais i portalo „Mano balsas" ${ }^{\text {“1 }}$ klausimus ir autoriaus atlikta Lietuvoje išrinktu EP narių balsavimo ideologiniais klausimais analize.

Kaip minèta, iki šiol Lietuvoje politiniai EP rinkimų rezultatai nebuvo analizuoti, o jų rezultatų analizė apsiribodavo publicistinio pobūdžio straipsniais. EP rinkimų rezultatai dažniau yra analizuojami Jungtinejje Karalystejje - daugiausia statistiniu aspektu arba siekiant nuspèti būsimus jų rezultatus ir paaiškinti, kaip rinkejjai traktuoja EP rinkimus (pavyzdžiui, M. Maršo darbai²). Kitas analizès aspektas, kuriuo remiamasi, - rinkimų kampanijų poveikis rinkejų dalyvavimui $^{3}$. Šiame darbe tokia analizè nebus atliekama dèl ypač blankios $2009 \mathrm{~m}$. rinkimų kampanijos (2009 m. EP rinkimų politinę analizę Vengrijoje pateikia Agnes Batory ${ }^{4}$.

Nurodytų darbų ižvalgomis bus remiamasi analizuojant Lietuvos atveji.

http://www.manobalsas.lt

2 Marsh, M. Vote Switching in European Parliament Elections: evidence from June 2004: Paper presented in the second meeting of EES group, 12-13 May, 2006 - http://www.ees-homepage.net/papers/ lisbon/marsh.pdf (žiūrèta $2009 \mathrm{~m}$. birželio 25 d.).

3 Banducci, S. Turnout in the 2004 European Parliamentary Elections: Campaigns and the Mobilization of Eurosceptic Voters: Paper prepared for presentation at the Institute for Governance Conference, Workshop Innovation of Governance. June 16-17, 2005. Universiteit Twente, Enschede, The Netherlands - http://www.ucd.ie/civicact/campaigns-euroscepticvoters.pdf (žiūrèta 2009 m. birželio 19 d.).

4 Batory, A. European Parliament Election Briefing No 25 The European Parliament Election In Hungary, June 72009 - http://www.sussex.ac.uk/sei/documents/epernep2009hungary.pdf (žiūrèta 2009 m. birželio 20 d.). 


\section{Dalyvavimas Europos Parlamento rinkimuose: antraeiliškumo ar nusivylimo požymis?}

Kaip pažymi dauguma tyrejjų (M. Maršas, Saimonas Hiksas (Simon Hix) ir kt. ${ }^{5}$ ), EP rinkimus rinkèjai traktuoja kaip antraeilius, tai yra turinčius mažesnès įtakos tiesioginei Vyriausybės politikai, taigi mažiau svarbius. Lietuvoje pirmaeiliais rinkimais laikytini Seimo ir Respublikos Prezidento rinkimai, kiti - antraeiliais. Kaip pažymi M. Maršas, antraeiliai rinkimai sulaukia mažesnio gyventojų dėmesio ir dalyvavimo. Išskiriamos dvi antraeilių rinkimų savybės.

Pirma, rinkèjai linkę balsuoti pagal preferencijas, bet ne remtis racionaliais išskaičiavimais (vadinamasis ,balsavimas širdimi“), nes numato menkas pasekmes (tai gali paaiškinti kraštutinių partijų sėkmę kai kuriose Vidurio Rytų Europos šalyse 2004 m.). Antra, antraeiliai rinkimai yra kaip priemonė požiūriui i Vyriausybės politiką pareikšti (,,referendumo efektas“). Pastarasis yra mažiau svarbus, jei EP rinkimai sutampa su Seimo rinkimais arba vyksta netrukus po jų (kaip 2009 m.), reikšmingesnis - jei Seimo kadencija būna ịpusèjusi arba eina i pabaigą (2004 m. atveju). A. Batory ${ }^{6}$ atkreipia dèmesị, kad didesnis nusivylimas Vyriausybe (Vengrijos atveju) taip pat skatina dalyvavimą, ir pabrèžia, kad dažniausiai EP rinkimuose vis dèlto dominuoja nacionalinès, o ne europinès politikos klausimai.

2009 m. birželio 7 d. Lietuvoje ịvykę rinkimai, palyginti su 2004-ujų, pasižymèjo rinkejju pasyvumu ir pasiekè dalyvavimo rinkimuose, îvykusiuose per visus 19 nepriklausomos Lietuvos gyvavimo metu, antirekordą. Toks rezultatas liudija, kad 2009-ujų rinkimai yra traktuotini kaip antraeiliai.

Žvelgiant į mažą rinkėjų aktyvumą kyla klausimai: kokios aplinkybès lèmė tokius prastus rodiklius, ir ar iš tiesu jie atskleidžia rinkèju abejingumą ES reikalams.

Pradedant lyginti EP rinkimų ir kitų rinkimų rezultatus verta pabrèžti, kad 2009 m. rinkimai yra pirmieji vien europiniai rinkimai, nesidubliuojantys su Respublikos Prezidento rinkimais, kaip tai įvyko 2004 metais. Todèl lyginti dalyvavimą 2004 ir 2009 metais nèra tikslu, nes 2004-uju EP rinkimai iš esmès laikytini Prezidento rinkimų priedu. Kartu jie atspindèjo būsimų Seimo rinkimų rezultatus.

5 Hix, S., Marsh, M. Punishment or Protest? Understanding European Parliament Elections - http:// sitemason.vanderbilt.edu/files/b4Neq4/Hix.pdf (žiūrèta 2009 m. birželio 22 d.).

6 Batory, A. European Parliament Election Briefing No 25 The European Parliament Election In Hungary, June 72009 - http://www.sussex.ac.uk/sei/documents/epernep2009hungary.pdf (žiūrèta $2009 \mathrm{~m}$. birželio 20 d.). 
Kur kas prasmingiau lyginti $2009 \mathrm{~m}$. i̇vykusių EP rinkimų rinkejjų aktyvumo rezultatus su $2003 \mathrm{~m}$. gegužès $10 \mathrm{~d}$. surengto referendumo „Dèl Lietuvos stojimo i Europos Sajunga“, kai Lietuvos gyventojai taip pat buvo paprašyti pareikšti savo nuomonę vien su ES susijusiu klausimu.

Pažymètina, kad aktyvumas pirmają referendumo dieną buvo ne ką didesnis nei 2009-aisiais. $2003 \mathrm{~m}$. referendume dalyvavo 23,01 proc. rinkèjų, $2009 \mathrm{~m}$. EP rinkimuose - 20,98 proc. Lyginant šiuos rodiklius matyti, kad rinkejjų aktyvumas sprendžiant išimtinai su Europos Sajunga susijusius klausimus per šešerius metus iš esmès nepakito. Galima teigti, kad tai patvirtina iškeltą rinkimų antraeiliškumo hipotezę.

Kita vertus, vertinant rinkimų rezultatus pagal regionus matomi labai ryškūs domèjimosi rinkimais, išimtinai susijusiais su ES, pokyčiai. Atkreiptinas dẻmesys, kad EP rinkimuose ypač aktyviai dalyvavo Šalčininkų ir Vilniaus rajonų gyventojai (tai leido Lietuvos lenkų rinkimų akcijai (toliau - LLRA) iškovoti vieną mandatą), nors referendume dèl stojimo į ES šiose savivaldybėse dalyvavimo rezultatai buvo vieni iš prasčiausių.

Tokia tendencija atspindi nuolat didejjantị Lietuvos lenkų aktyvumą rinkimuose po Lietuvos įstojimo į ES. 5 proc. rinkimų slenkstị LLRA, kooperuodamasi su rusu partijomis (pirmiausia - su nuo Lietuvos rusų sajungos atsiskyrusia politine partija ,Rusų aljansas“, veikiančia Klaipėdoje), peržengia jau antruose EP rinkimuose. $2004 \mathrm{~m}$. LLRA gauta balsų kvota nebuvo pakankama užsitikrinti vietą EP, tačiau 2009-aisiais, sumažejjus rinkejjui aktyvumui, jai pavyko tai padaryti. Lenkų tautybės gyventojų aktyvumas EP rinkimuose (jis atsikartojo ir Seimo rinkimuose 2008 m.) rodytu, kad narystė ES sustiprino Lietuvos lenkų politinę mobilizaciją. To priežastys galètų būti tiek atsivèrusios lengvesnès bendradarbiavimo su Lenkija ir jos politinèmis jègomis perspektyvos, galimybe EP šlietis prie lenkų parlamentarų, tiek stiprejantis Lietuvos lenkų tautinis tapatumas, kuri skatina LLRA. Svarbus ir strateginis aspektas - sajunga su Klaipėdoje veikiančia, rusų tautinei mažumai atstovaujančia partija; tai lèmé, kad LLRA Klaipėdoje buvo penkta pagal surinktų balsų kieki (žr. 1 lentelę). Ši sajunga padeda išvengti tokios tautinių mažumų tarpusavio konkurencijos dèl balsų kaip Vilniuje ir leidžia juos surinkti skirtingose vietovèse. 
Diagrama. Rinkejjų dalyvavimas rinkimuose Šalčininkų(1) ir Vilniaus (2) rajonuose 2003-2009 m.

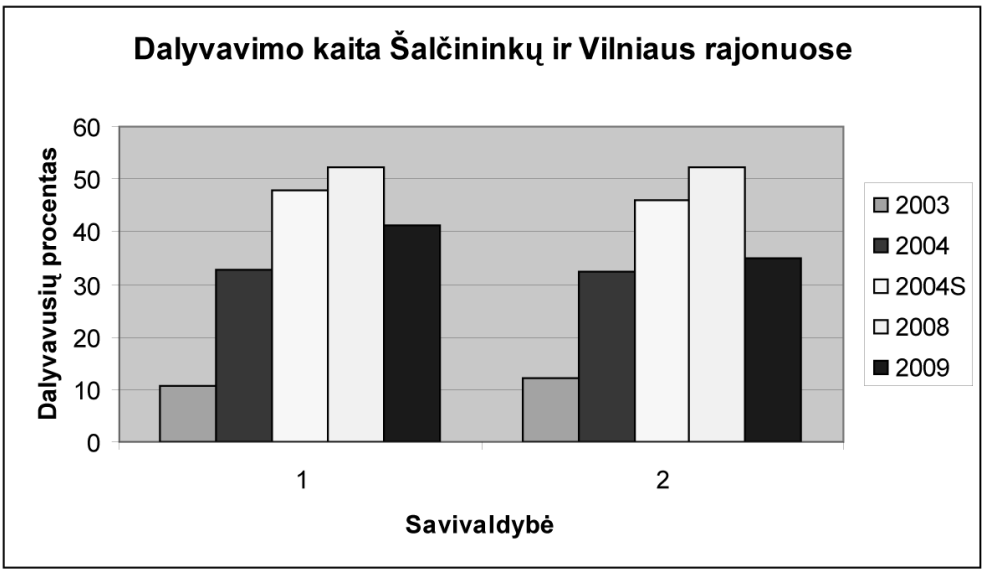

Apskritai vietovėse, kuriose gyvena daug lenku, 2009 m. rinkimuose aktyvumo rodikliai yra didžiausi. Šiuose rinkimuose gyventojų dalyvavo daugiau nei $2003 \mathrm{~m}$. referendumo pirmają dieną pusèje (30) savivaldybių. Didelis rinkèjų aktyvumas užfiksuotas Šilalëje, Raseiniuose, Pagègiuose, čia jis išliko panašus į 2003-aisiais įvykusio referendumo rezultatus. Labiausiai kritęs, palyginti su 2003 m., aktyvumas - didžiuosiuose miestuose (per 9 proc.), išskyrus Vilniu. Vis dèlto tendencijos neleidžia teigti, kad ES reikalai Lietuvos gyventojams rūpi mažiau nei 2003 m., kaip neleidžia teigti, jog jie rūpi ir daugiau. 
1 žemèlapis. Dalyvavimo pokytis tarp 2003 m. ir 2009 m.

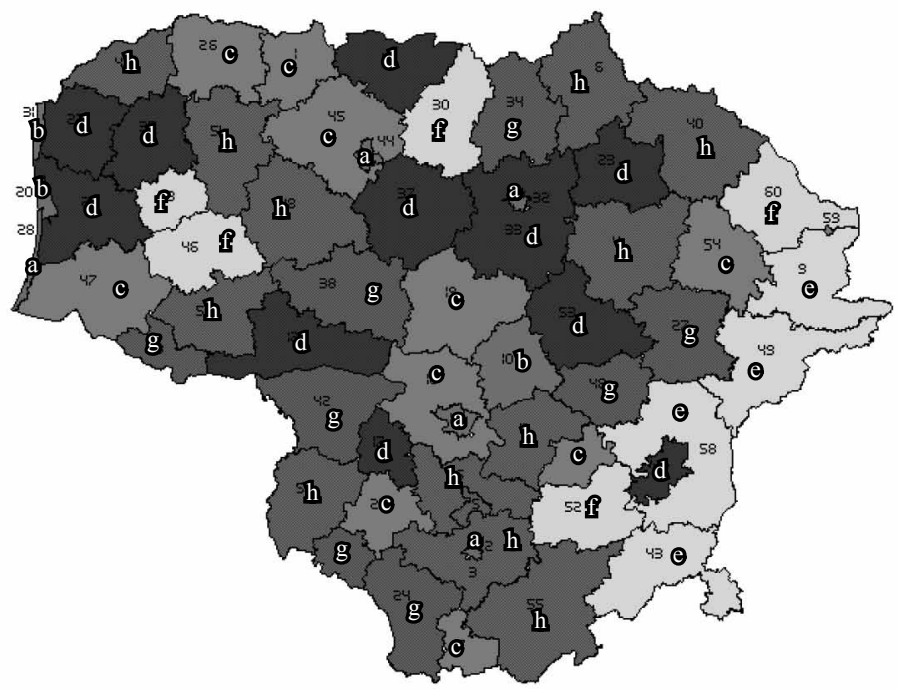

\begin{tabular}{|c|c|}
\hline Smuko & Išaugo \\
\hline a Daugiau nei 9 proc. & e Daugiau nei 9 proc. \\
\hline b 6-9 proc. & f 6-9 proc. \\
\hline c 3-6 proc. & g 3-6 proc. \\
\hline d Iki 3 proc. & h Iki 3 proc. \\
\hline
\end{tabular}

Palyginti pasyvus dalyvavimas rinkimuose Lietuvoje išryškino ir lyderystès krizès tendencijas, pastebètas jau $2008 \mathrm{~m}$. Seimo rinkimuose. Nors rinkimuose ir dalyvavo partijų lyderiai, rinkèjai nebuvo aktyvūs. Tai gali liudyti, kad gyventojai tiesiog nematè prasmès dalyvauti ir paremti kandidatuojančiu politikų. Tokia situacija padidino politikų, isitvirtinusių atskirose apygardose, galimybes. Šią tendenciją gerai iliustruoja Zigmanto Balčyčio pirmavimas Šilalèje ir Šilutèje, kur jis aplenkè visus kitus kandidatus, buvusio Pagègiu mero Kęsto Komskio pirmavimas prieš Rolandą Paksą Pagėgių savivaldybejje, Remigijaus Ačo - Raseinių rajone, Dalios Štraupaitès pirmavimas prieš Artūrą Zuoką Visagine ir panašiai.

Apibendrinant galima teigti, kad bendras euroentuziazmo lygis, palyginti su 2003 m., yra nepakitęs, labiausiai EP rinkimais domisi lenkų tautybès rinke்- 
jai, kurie antrą kartą (aljanse su Klaipėdoje veikiančia politine partija „Rusų aljansas") sudaro galimybes lenkų ir rusų partijų aljansui peržengti 5 proc. barjerą.

Lietuvos atveju iš esmès pasitvirtina rinkimų antraeiliškumo hipotezė. Be to, kaip matyti iš Lietuvos lenkų atvejo, pasitvirtina prielaida, kad į rinkimus labiau linkę ateiti tie rinkejjai, kurie nepatenkinti padètimi.

Atsižvelgiant $\mathfrak{i}$ tai, kad TS-LKD turi stabiliausią elektoratą ir elektoriniu atžvilgiu yra labiausiai institucionalizuota Lietuvos politine partija ${ }^{7}$, jos pergalè antraeiliuose rinkimuose atitinka M. Maršo suformuluotą teoriją ${ }^{8}$.

\section{2009 m. Europos Parlamento rinkimų rezultatų itaka Lietuvos partinès sistemos raidai}

Vertinant rinkimų rezultatus akivaizdu, kad ištikimiausius rinkejjus turi dvi politinès partijos - TS-LKD ir LSDP. Šios partijos surinko daugiausia balsų $5 / 6$ savivaldybių. 28 savivaldybėse pirmają vietą pagal surinktų balsų skaičiu užėmè TS-LKD, 22 - LSDP. Trečioje vietoje liko LLRA, laimèjusi 4 savivaldybèse, „Tvarka ir teisingumas“-3, Darbo partija (toliau - DP) - 2. Ignalinoje po lygiai balsu gavo LSDP ir LVLS. Analizuojant balsavimo rezultatus pagal rajonus matyti, kad LSDP ir TS-LKD iš esmès pasidalijo 1-2 vietas daugiau nei $2 / 3$ savivaldybių (41). Taip pat antrą vietą neretai užimdavo TiT -5 savivaldybèse.

7 Kluonis, M. Politinių partijų teritorinès institucionalizacijos bruožai Lietuvoje: ketverių Seimo rinkimų analizè. Lietuva po Seimo rinkimu 2008. Vilnius, 2009.

8 Marsh, M. Vote Switching in European Parliament Elections: Evidence from June 2004: Paper presented in the second meeting of EES group, 12-13 May, 2006 - http://www.ees-homepage.net/ papers/lisbon/marsh.pdf (žiūrèta 2009 m. birželio 25 d.). 
2 žemèlapis. Pirmų vietų pasiskirstymas pagal politinių partijų gautus balsus savivaldybèse

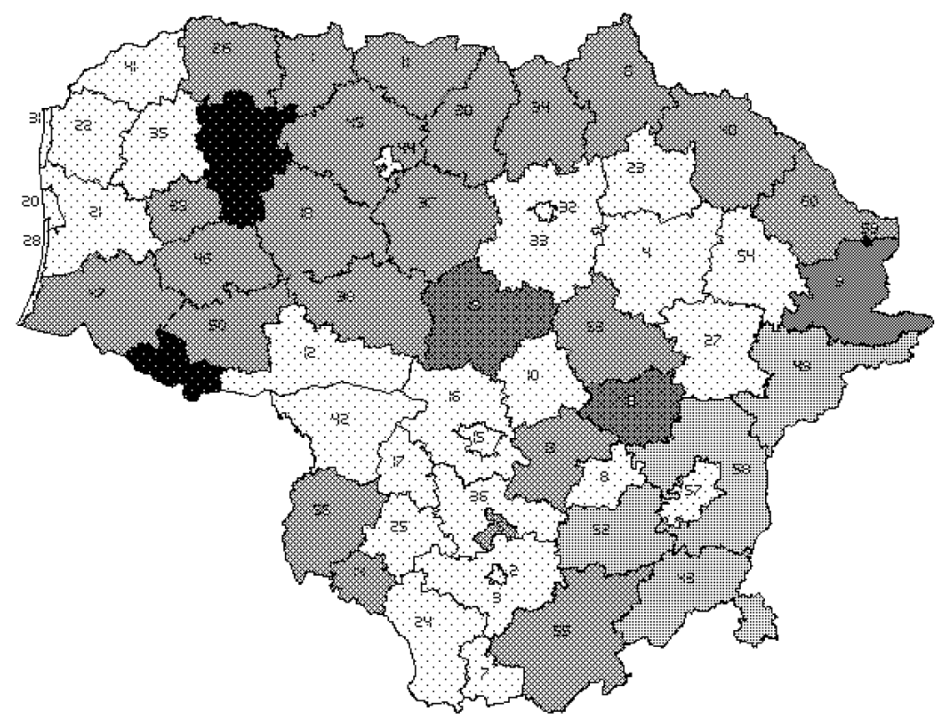

\begin{tabular}{|c|c|c|c|}
\hline$\because$ & TS-LKD & 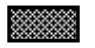 & DP \\
\hline 网 & LSDP & & $\mathrm{TT}$ \\
\hline & LSDP/LVLS & म & LLRA \\
\hline
\end{tabular}


EP rinkimų rezultatai, atsižvelgiant i̇ rinkẻju pasyvumą, kuris, tikètina, gali toks išlikti ne tik per EP, bet ir per Seimo rinkimus, rodytu, kad Lietuvos partinè sistema evoliucionuoja 3,5 partijų modelio link, kurioje du dominuojantys poliai būtų TS-LKD ir LSDP. Trečioji partija, kuri neleidžia susiformuoti vokiškai 2,5 partinei sistemai, yra TiT, atliekanti ,,antisisteminès“ partijos vaidmeni. Būtent šios partijos, kaip neturinčios koalicinio potencialo su kitomis dominuojančiomis partijomis (TS-LKD ir LSDP), stiprus isitvirtinimas visoje valstybèje (užimta 3-4 vieta, net esant mažam rinkẻjų aktyvumui) ir potencialas sutelkti apie save kitas dviem pagrindinėms partijoms oponuojančias jëgas - DP, LVLS (Seimo opozicinès koalicijos po EP rinkimų $2009 \mathrm{~m}$. atveju) ir iš dalies LLRA - yra pagrindinè kliūtis șsitvirtinti dviejų blokų(TS-LKD ir LS - dešinëje, LSDP ir DP (arba kuri nors kita partija) - kaireje) sistemai.

Schema. Politiniu partijų laukas Lietuvoje (paryškintos polinės partijos, pabrauktos - jungiančiosios)

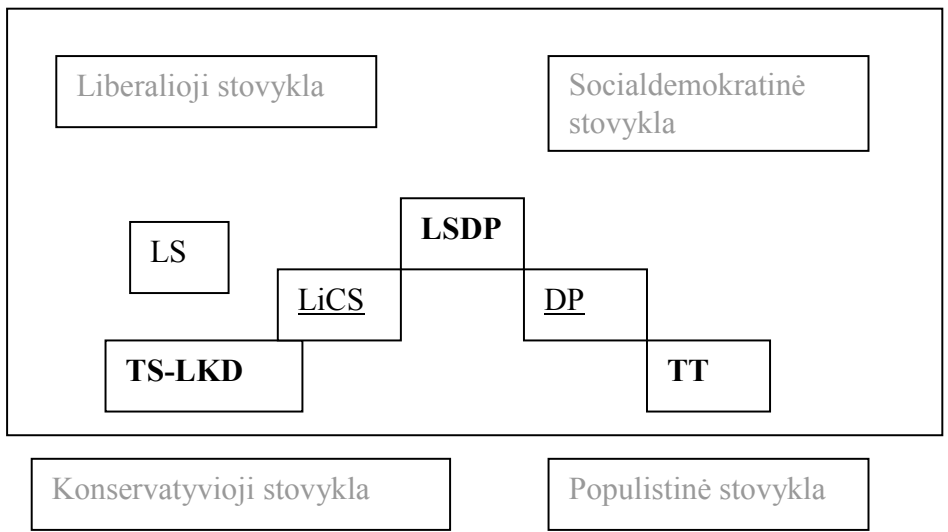

Žvelgiant iš ES reikalųperspektyvos TiT atstovauja iš esmès euroskeptiniam, bentjau tautiškai konservatyviam elektoratui, pasisakančiam už didesnį nacionalinių vyriausybių vaidmenį ES, ypač kultūros srityje. Tokiąjos poziciją rodytų ir polinkis EP jungtis prie grupès Sajunga „Už tautų Europac“ ar kitos euroskeptinès grupès. Geri TiT rezultatai rodo, kad euroskeptinė politika Lietuvoje turi perspektyvu. Kita vertus, iš nacionalinès politikos pasitraukus jos lyderiui R. Paksui, tikètina, kad partijos svoris ir populiarumas ilgainiui gali pradèti mažèti.

Kalbant apie tautiškai konservatyvią ir euroskeptinę poziciją vertėtų palyginti TiT ir 
kitųEP rinkimuose dalyvavusių partijų kurios galètųjungtis prie euroskeptinių frakcijų EP, rezultatus. Pirmiausia - akivaizdu, kad vien nacionalizmo idejjas propaguojančios partijos yra autsaiderès ne tik nacionaliniuose, bet ir EP rinkimuose. Palyginti geras Lietuvos centro partijos (toliau - LCP) rezultatas, tikètina, yra daugiau Onos Juknevičienės asmeninės charizmos nei pačios partijos laimėjimas (atsižvelgiant i prastą partijos pasirodymą rinkimuose esant kitiems lyderiams). Kita rinkimuose dalyvavusi nacionalistinè partija - „Lietuvos kelias“ - patyre visišką pralaimèjimą.

Galima išskirti dvi pagrindines priežastis, kodèl nacionalistinès partijos nèra populiarios. Pirmoji priežastis - atviras priešiškumas ES ir net bandymai kelti idèjas apie galimą Lietuvos išstojimą iš ES, trečio kelio paieškas. Tokios idèjos prasilenkia su daugumos rinkèjų interesais, nes Lietuvos piliečiai yra pajutę ES bendrosios rinkos, pirmiausia - laisvos darbo jègos ir kapitalo judejjimo, taip pat Šengeno sutarties - privalumus. Dèl jų 2006-2008 metais buvo faktiškai ne tik išsisprendusi nedarbo problema, aktuali Lietuvai nuo pat nepriklausomybės atgavimo, bet ir susidare sąlygos tėvynejje likusiems piliečiams pagerinti savo buiți: dẻl darbo jègos trūkumo siekiant didesnių atlyginimų ir per ES dirbančių artimujų finansinę paramą. Verslas taip pat pajuto ES privalumus, nes emigracija padidino ir vidaus vartojima, be to, atsirado galimybė panaudoti ES struktūrinę paramą, buvo sukurta naujų darbo vietų. Todèl neturètų stebinti, kad daugumai piliečių nelabai priimtina mintis atsisakyti ekonominès gerovės dèl abstrakčių tautiškumo išgryninimo idejųu. Euroentuziastès $\mathrm{O}$. Juknevičienès dalyvavimas rinkimuose LCP sąrašuose ir jos pasiekti rezultatai taip pat gali liudyti, kad net patys tokių partijų lyderiai suvokia savo situacijos beviltiškumą.

Antroji priežastis - tokių partijų nepajëgumas ideologiškai konkuruoti su varžovėmis, pretenduojančiomis į euroskeptikų elektoratą, bet siūlančiomis likimo ES perspektyvą ir sieki ją pakeisti iš vidaus. Tokia pozicija būdinga TiT, kuri reiškia nepasitenkinimą ES ir gana sèkmingai save pateikia kaip ,antielitinę“ jègą tiek ES, tiek Lietuvoje. TiT situacija yra paradoksali. Viena vertus, partija pasisako už nacionalizmą, bet kita vertus, yra siejama su Rusija. Šis faktas didina jos galimybes pritraukti tiek rusų tautybès (partija užèmè pirmają vietą Visagine), tiek nacionalistinį elektorata, taip pat menkina ,grynujų“ nacionalistu galimybes. Be to, i nacionalistines jègas dèl istorinių aplinkybių (Sajūdžio) žiūrima ir kaip i̇ natūralią radikalaus TS-LKD sparno dali, todèl gali būti linkstama labiau rinktis motininę, didesnę partiją. Aiškiųnuostatų socialiniais klausimais trūkumas stiprina nacionalistinių partijų priskyrimo radikaliajam TS-LKD sparnui tendenciją ir silpnina galimybes konkuruoti su TiT, pasisakančia už perskirstymo politiką.

Dèl minètų priežasčių TiT gali prisistatyti kaip pagrindinè euroskeptinè partija Lietuvoje ir alternatyva proeuropietiškoms partijoms.

Pastebėtina, kad vis deltto stiprioji TiT puse yra ne euroskeptiškumas, bet, ,antielitiškumas“. Kaip pažymi M. Maršas, partijų požiūris i europinius reikalus nèra lemiamas veiksnys renkantis, už kurią partiją balsuoti EP rinkimuose ${ }^{9}$. Labai aiškiai ši tendencija

9 Ten pat. 
atsispindi Tautos prisikèlimo partijos (toliau - TPP) Lietuvoje ir „Libertas“ partijos nesėkmès europiniu mastu atvejais.

Kitos politinès sistemos požiūriu svarbios partijos, atsižvelgiant i EP rinkimų rezultatus, yra Liberalų sajūdis (toliau - LS) ir DP (jos priklauso Liberalų ir demokratų aljansui Europai (ALDE). Šios partijos, ypač DP (kartu su Liberalų ir centro sajunga ir Lietuvos valstiečių liaudininkų sajunga), sudaro tą pusinį elementą, kuris gali veikti koalicijų susidarymą nacionaliniu lygmeniu. Kaip parodè rinkimai, darbiečiai ir liberalai geba išlikti politinëje arenoje net esant mažam rinkèjų aktyvumui (antruoju atveju svarbų vaidmeni, tikètina, suvaidino ir Leonido Donskio vardas kandidatų sąraše). Funkcionuodamos kaip partinès sistemos jungtys, DP ir LiCS nèra pajègios tapti tokiais pagrindiniais veikejais kaip TS-LKD, LSDP ir TiT, tačiau gali lemti koalicijų sudarymą. Kita vertus, šių partijų galimybes riboja jų koalicinis potencialas ir nuostatos. LS atveju tokį apribojimą sukuria nenoras bendradarbiauti su LSDP ir ,antisisteminemis“ partijomis (TiT, DP), o tai faktiškai paverčia partiją TS-LKD satelitu, nes nelieka galimybès sudaryti koaliciją su kitais svarbesniais partinès sistemos veikejjais. DP pasirinkimo galimybės nacionaliniu lygmeniu yra didesnès, nes ji, jungdama populistinį ir kairiji blokus, susiklosčius palankioms aplinkybėms gali lemti kairiosios arba populistinės Vyriausybės sudarymą. Vis dèlto šios partijos galimybes riboja TS-LKD nenoras sudaryti su ja koalicija, ir tai smarkiai mažina jos svarbą partinèje sistemoje ir neleidžia ịsitvirtinti kaip esminei koalicinių vyriausybių formavimo jègai.

Su tokiomis problemomis susiduria ir analogiškoje situacijoje esanti mažiau populiari LVLS. Pastaroji partija 2004-2009 m. EP prisijungè prie Sajungos „Už tautų Europą“, šis žingsnis europinès politikos lygmeniu daro ją artimesnę TiT nei LSDP. Po EP rinkimų TiT, DP ir LVLS suformavus bendrą opozicijos bloką Seime, tokia tendencija dar labiau sustiprèjo. Galima daryti prielaida, kad vienas iš tokio poelgio tikslų - stabdyti dviejų blokų sistemos formavimąsi Lietuvoje.

LiCS pralaimèjimas EP rinkimuose rodytu, kad ši partija praranda savo politini svorị ir nesugeba išlaikyti pakankamo ištikimo elektorato. Tikètina, kad prie to prisideda ir jos buvusio lyderio Artūro Zuoko problemos su teisèsauga. Ši tendencija partinès sistemos atveju reiškia skatinimą formuotis trijų blokų (konservatyvaus - liberalaus, socialdemokratinio ir populistinio) sistemai, nes LiCS dèl savo plataus koalicinio potencialo veikè kaip svarbi partija susidarant dešinès ar kairès koalicijoms. LiCS pralaimëjimas patvirtina $2008 \mathrm{~m}$. Seimo rinkimuose susiformavusią tendenciją, kad jungtis formuojančių partiju, turinčių platų koalicini potencialą, vaidmuo mažèja. Tai gali reikšti didejjančią politinę poliarizaciją nacionalinèje politikoje.

Prieš aptariant didžiujuc politinių partijų - TS-LKD ir LSDP - rezultatus, vertètų apžvelgti kitų rinkimuose dalyvavusiu partijų laimèjimus. Pirmiausia tenka pažymèti, kad Tautos prisikèlimo ir Pilietinès demokratijos (toliau - PDP) partijos nesugebejo pritraukti nuolatinio rinkejo. TPP nesėkmingai bandè pritaikyti Lietuvoje paneuropinès partijos „Libertas“ idejjas ir pabrèžè kovą su ES biurokratija, 
nacionalinių valstybių vaidmens stiprinimą, pretenduodama į tą pačią nišą kaip ir TiT. Sprendžiant iš EP rinkimų rezultatų, tokia pretenzija nebuvo sėkminga, nes, kaip minèta, TiT yra išplètojusi gana daugiapusę poziciją kurios kertinis elementas - oponavimas sistemai. O TPP suvokiama kaip sistemos dalis. 2009 m. EP rinkimai aiškiai parode, kad euroskepticizmo nišą Lietuvoje užima ir stiprias pozicijas joje išlaiko TiT, tad ją išstumti gali būti labai sunku. Ši uždavini galbūt galètų igyvendinti TS-LKD, tačiau kitos partijos tokių galimybių neturi. EP rinkimai turètų atkreipti TPP dėmesi, kad jai reikalingas kitoks ideologinis pamatas. Ir tai yra ženklas EP rinkimuose dalyvaujančioms partijoms, kad rinkimų kampanijose pirmiausia verta koncentruotis į nacionalinès politikos, o ne ES struktūros klausimus.

PDP iš esmès vertintina kaip „vienos problemos“ partija. Tokia ji tapo Valstybės saugumo departamento veiklos tyrimo metu ir šio įvaizdžio atsikratyti nesugeba. Dèl to labai sumažèja jos galimybès gerai pasirodyti rinkimuose, ypač atsižvelgiant i tai, kad laikosi panašios pozicijos kaip TS-LKD.

Nesėkmingas „Fronto“ partijos pasirodymas EP rinkimuose signalizuoja, kad sovietinès nostalgijos eksploatavimo taip pat neužtenka, norint užsitikrinti pakankamą rinkèjų parama.

EP rinkimai parodė, kad Lietuvoje stiprejja regioninès partijos. Žemaičių partijos perspektyvos yra miglotos, nes ji yra kiek populiaresnè tik keliose Žemaitijos savivaldybėse, tačiau LLRA ir Klaipèdos rusųpolitinès partijos „Rusųaljansas“koalicija EP rinkimuose dar kartą irodè savo veiksmingumą. Esant mažam rinkẻjų aktyvumui ši politinè jèga sugebejo laimèti 4 savivaldybėse ir pasiekti neblogų rezultatų dviejuose didžiuosiuose Lietuvos miestuose - Vilniuje ir Klaipėdoje (taip peržengė 5 proc. barjera). Geras LLRA pasirodymas taip pat atskleidžia stiprëjančią politinę poliarizaciją Lietuvos politikoje balsuojant pagal tautybę. LLRA pergalè stiprina konservatyvių Lenkijos jëgų pozicijas EP, o pats LLRA atstovas, tikètina, jungsis prie dešiniujų frakciju.

TS-LKD pergalė EP rinkimuose atitinka bendrą Europos tendenciją. Nacionaliniu lygmeniu TS-LKD pademonstravo, kad turi stiprų elektoratą pirmiausia visuose didžiuosiuose Lietuvos miestuose, taip pat Pajūrio, Panevėžio, Utenos ir Pietvakarių Lietuvos savivaldybėse. TS-LKD citadele išlieka Kaunas ir Kauno rajonas, kuriame stipri partijos institucionalizacija, taip pat Panevėžys. Kiek netikètas TS-LKD rezultatas - antroji vieta - Pasvalio rajone, nes čia, skirtingai nei visoje Šiaurès Lietuvoje, partija visą laiką būdavo pirma. Vis dèlto EP rinkimuose ir šis rajonas neatsiliko nuo bendros Šiaurès Lietuvos tendencijos. Gali būti, kad Pasvalio rajone suveikè referendumo ir antraeiliškumo principu derinys - atèjo balsuoti situacija nepatenkinti piliečiai, o TS-LKD palaikantys rinkejai liko namuose. EP rinkimai taip pat atskleidè TS-LKD elektorato plètros potencialą bei galimas jo kryptis, tai yra tolesnį dešiniujų jẻgų vienijimąsi.

Pirmoji plètros kryptis - vienijimasis su buvusio Ministro Pirmininko Gedimino Vagnoriaus vadovaujama Krikščionių konservatorių socialine sajunga, kuri 9 savivaldybèse užèmė 5 vietą. Tokie rezultatai rodo, kad proeuropietiškų krikščionių demokratų 
potencialas dar nėra išsemtas. Toks vienijimasis sustiprintų proeuropietišką partijos sparnąir jo lyderio Andriaus Kubiliaus pozicijas partijoje. Kita vertus, tokia perspektyva yra miglota dèl politinių nuoskaudu, atsiradusių dar 2000 m., kai Gedimino Vagnoriaus grupè atsiskyrè nuo tuometinès TS.

Kitas kelias - bandyti pritraukti euroskeptišką, tautiškai konservatyvų elektoratą ir taip eliminuoti TiT. Euroskeptinès tendencijos TS-LKD sustiprèjo, kai i ją isijungė Lietuvos tautininkų sajunga (toliau - LTS), nors euroskeptikams būdingų idejų partijoje buvo galima rasti ir anksčiau. Vis dèlto šis variantas, nors ir galètų išplèsti rinkejjų mastą, keltų sunkumų, nes reikštų partijos posūkị populistinès politikos link, ir tai galètų lemti partijos skilima, ją susilpnintų. Be to, TS-LKD, priklausydama Europos liaudies partijos - Europos demokratu frakcijai, turi didesnę itaka, nei igytu, prisijungusi prie kuriamos Europos konservatorių ir reformistų grupès ar Sajungos „Už tautų Europą“.

Kitas pakankamai aiškus rinkimų nugalètojas - LSDP, tradiciškai gavusi daug balsų savo pagrindinėse tèvonijose - Pakruojo, Šilalès, Šilutès, Vilkaviškio rajonuose. Kaip pagrindinį balsavimo už šią partiją regioną galima išskirti Latvijos pasienio rajonus, Pietų Žemaitija. Vakarų Aukštaitiją. LSDP stiprioji pusè - kandidatų įitvirtinimas atskiruose rajonuose, tačiau ši stiprybė gali gana lengvai tapti trūkumu, jeigu kandidatas nedalyvautų rinkimuose, nes yra tikimybè, kad rinkèjai rinktussi kitą partiją. LSDP rezultatai parodè, kad ji taip pat turi pakankamai ištikimą rinkèją. Jei tęstųsi jungtis formuojančių partijų nykimo tendencija, imanoma, kad LSDP perimtų nuosaikiausią DP sparną o kita DP dalis galètų isilieti i TiT. Geras LSDP pasirodymas rinkimuose patvirtina M. Maršo hipotezę, kad i antraeilius rinkimus ateina daugiau opoziciją remiančių rinkejjų. Vis dèlto vertètų pastebèti, kad geresné TS-LKD teritorinè ir elektorinè institucionalizacija stiprina jos pozicijas prieš LSDP, todèl pastarajai reikètų didinti įtaką savivaldybèse ir ypač didžiuosiuose miestuose, kuriuose partija pasirodo gana prastai.

Tęsinys p. 146 
1 lentele. Partijų pozicijų pasiskirstymas savivaldybėse (paryškinti rezultatai - skirtumas tarp pirmos ir antros vietos viršija 15 proc.)

\begin{tabular}{|c|c|c|c|c|c|c|}
\hline Savivaldybė & \begin{tabular}{|c} 
Skirtu- \\
mas tarp \\
dalyvavimo \\
referendumo \\
pirmąją die- \\
ną $2003 \mathrm{~m}$. ir \\
EP rinkimų \\
$2009 \mathrm{~m}$.
\end{tabular} & 1 vieta & 2 vieta & 3 vieta & 4 vieta & 5 vieta \\
\hline Akmenès & $-3,48$ & LSDP & TT & DP & TS-LKD & LCP \\
\hline Alytaus miesto & $-10,53$ & TS-LKD & LSDP & TT & $\mathrm{DP}$ & LS \\
\hline Alytaus rajono & $+2,21$ & TS-LKD & LSDP & TT & $\mathrm{DP}$ & KKSS \\
\hline Anykščiu & $+2,41$ & TS-LKD & LSDP & DP & TT & KKSS \\
\hline Birštono & $+1,00$ & LSDP & TS-LKD & TT & LS & DP \\
\hline Biržu & $+2,23$ & LSDP & TS-LKD & TT & $\mathrm{DP}$ & LVLS \\
\hline Druskininku & $-5,55$ & TS-LKD & LSDP & TT & DP & LS \\
\hline Elektrènų & $-5,18$ & TS-LKD & LSDP & TT & DP & LiCS \\
\hline Ignalinos & $+10,57$ & LSDP & LVLS & TS-LKD & TT & DP \\
\hline Jonavos & $-8,92$ & TS-LKD & LSDP & DP & TT & LVLS \\
\hline Joniškio & $-0,13$ & LSDP & TT & TS-LKD & DP & LS \\
\hline Jurbarko & $-1,33$ & TS-LKD & LSDP & TT & DP & KKSS \\
\hline Kaišiadorių & $+1,69$ & LSDP & TS-LKD & DP & TT & LS \\
\hline Kalvarijos & $+4,95$ & LSDP & TS-LKD & DP & TT & LS \\
\hline Kauno miesto & $-10,99$ & TS-LKD & LSDP & LS & TT & DP \\
\hline Kauno rajono & $-5,29$ & TS-LKD & LSDP & LS & TT & DP \\
\hline Kazlų Rūdos & $-2,56$ & TS-LKD & LSDP & TT & DP & LS \\
\hline Kelmès & $+1,21$ & LSDP & TS-LKD & TT & DP & LiCS \\
\hline Kèdainių & $-3,12$ & DP & LSDP & TS-LKD & TT & LS \\
\hline Klaipédos miesto & $-7,23$ & TS-LKD & LS & TT & LSDP & LLRA \\
\hline Klaipèdos rajono & $-1,72$ & TS-LKD & TT & LSDP & LS & DP \\
\hline Kretingos & $-1,47$ & TS-LKD & LSDP & TT & DP & LS \\
\hline Kupiškio & $-1,93$ & TS-LKD & LSDP & DP & TT & LVLS \\
\hline Lazdiju & $+5,29$ & TS-LKD & LSDP & DP & TT & KKSS \\
\hline Marijampolès & $-4,63$ & TS-LKD & LSDP & TT & DP & LS \\
\hline Mažeikių & $-4,33$ & LSDP & TT & TS-LKD & $\mathrm{DP}$ & Žemaičių p. \\
\hline Molètų & $+3,13$ & TS-LKD & LSDP & DP & TT & KKSS \\
\hline Neringos & $-22,78$ & TS-LKD & LSDP & LS & TT & DP \\
\hline Pagègiu & $+3,73$ & TT & LSDP & TS-LKD & $\mathrm{DP}$ & LVLS \\
\hline
\end{tabular}




\begin{tabular}{|c|c|c|c|c|c|c|}
\hline Pakruojo & $+6,99$ & LSDP & TS-LKD & DP & TT & KKSS \\
\hline Palangos & $-8,45$ & TS-LKD & LSDP & LS & TT & $\mathrm{DP}$ \\
\hline Panevėžio miesto & $-9,08$ & TS-LKD & LSDP & TT & LS & DP \\
\hline Panevėžio rajono & $-2,55$ & TS-LKD & LSDP & DP & TT & LS \\
\hline Pasvalio & $+3,46$ & LSDP & TS-LKD & DP & TT & KKSS \\
\hline Plungès & $-1,39$ & TS-LKD & LSDP & TT & DP & Žemaičiųp. \\
\hline Prienu & $+1,91$ & TS-LKD & LSDP & TT & DP & LS \\
\hline Radviliškio & $-2,59$ & LSDP & TS-LKD & DP & TT & LS \\
\hline Raseinių & $+4,68$ & LSDP & TT & TS-LKD & DP & LS \\
\hline Rietavo & $+7,90$ & LSDP & TS-LKD & $\mathrm{TT}$ & DP & Žemaičiųp. \\
\hline Rokiškio & $+2,28$ & LSDP & TS-LKD & TT & DP & LVLS \\
\hline Skuodo & $+2,69$ & TS-LKD & TT & LSDP & $\mathrm{DP}$ & Žemaičių p. \\
\hline Šakiu & $+3,11$ & TS-LKD & LSDP & TT & LVLS & DP \\
\hline Šalčininku & $+30,85$ & LLRA & DP & TT & LSDP & TS-LKD \\
\hline Šiaulių miesto & $-9,79$ & TS-LKD & LSDP & TT & DP & LS \\
\hline Šiaulių rajono & $-3,55$ & LSDP & TS-LKD & TT & DP & LS \\
\hline Šilalès & $+7,27$ & LSDP & TS-LKD & TT & PDP & DP \\
\hline Šilutès & $-4,81$ & LSDP & TS-LKD & TT & LS & DP \\
\hline Širvintu & $+3,93$ & DP & LSDP & TS-LKD & TT & LLRA \\
\hline Švenčioniu & $+11,16$ & LLRA & DP & TT & LSDP & TS-LKD \\
\hline Tauragès & $+0,76$ & LSDP & TS-LKD & TT & DP & LiCS \\
\hline Telšių & $+2,33$ & TT & LSDP & TS-LKD & DP & KKSS \\
\hline Traku & $+7,67$ & LLRA & TS-LKD & LSDP & DP & TT \\
\hline Ukmergès & $-0,39$ & LSDP & TS-LKD & DP & TT & LS \\
\hline Utenos & $-3,12$ & TS-LKD & LSDP & TT & DP & LS \\
\hline Varėnos & $+2,57$ & LSDP & TS-LKD & $\mathrm{LCP}$ & TT & DP \\
\hline Vilkaviškio & $+0,53$ & LSDP & TS-LKD & TT & DP & KKSS \\
\hline Vilniaus miesto & $-2,74$ & TS-LKD & LSDP & LLRA & LS & TT \\
\hline Vilniaus rajono & $+22,59$ & LLRA & TS-LKD & TT & DP & LSDP \\
\hline Visagino & $-3,07$ & TT & LiCS & LSDP & $\mathrm{DP}$ & LLRA \\
\hline Zarasų & $+6,52$ & LSDP & TS-LKD & TT & $\mathrm{DP}$ & LVLS \\
\hline
\end{tabular}

Ivertinus EP rinkimų rezultatus, galima daryti išvadas apie Lietuvos partinės sistemos raidą. Pirmiausia pastebėtina, kad Lietuvos politinè sistema, esant pasyvesniam rinkejjų dalyvavimui, linkusi poliarizuotis, o jungtis formuojančios politinès partijos gauna mažiau balsų už tas, kurios pretenduoja būti koalicijų centrais. Jeigu tokia tendencija tęsis, ateityje gali būti formuojamos tik didžiosios koalicijos, tai yra gali susiformuoti pakankamai nelankstūs blokai, kuriems tektų sudaryti formalias (siekiant formuoti daugumos vyriausybe) ar neformalias (formuojant mažumos vyriausybę) sajungas. 
Apžvelgti duomenys taip pat liudija poreiki partijoms stiprinti rinkèjų institucionalizaciją. Kai pirmaeiliuose rinkimuose didesnis dalyvaujančiu piliečiu skaičius amortizuoja institucionalizacijos trūkuma, tai per antraeilius rinkimus stipri rinkejjų institucionalizacija tampa esminiu veiksniu, lemiančiu partijos sèkmę.

Gauti rezultatai patvirtina M. Maršo keliamą hipotezę, kad balsuojant lemiamą itaką turèjo ne europinès, bet nacionalinès politikos problemos. Tačiau nepatvirtina „balsavimo širdimi“ hipotezès, nes rinkimuose balsuota ne už partijas, linkusias $\mathfrak{i}$ ekstremizmą, nors kai kurie teoriniai modeliai teigia, kad antieuropinès partijos turètu geriau pasirodyti EP rinkimuose ${ }^{10}$. Toks rezultatas gali reikšti, kad Lietuvos piliečiai iš esmès yra patenkinti šalies buvimu ES ir jos funkcionavimu.

\section{Europos Parlamento ir nacionalinių politinių spektrų santykis}

$2007 \mathrm{~m}$. spaudos konferencijoje vienas žymiausių EP tyrinėtojų S. Hiksas atkreipè dèmesį, kad EP vis labiau linkęs remtis partinèmis-ideologinèmis takoskyromis ${ }^{11}$. Nuolat keisdamos pavadinimus, pagrindinès EP grupès iš esmès išsilaiko nuo pat EP isteigimo. Sunkiausiai savo pozicijas išlaikyti ir susiburti i grupę sekasi nacionalistinėms partijoms, kaip antai jų bandymas ikurti savą grupe „Identitetas, tradicija, suverenumas“ 2007-aisiais patyrè nesėkmę dèl sudarančių partijų tarpusavio kovų.

Šiuo metu EP veikia 7 grupès, o 2009 m. birželio mèn. isteigta nauja - Europos konservatoriu ir reformistu grupè (ECRG). Po šios grupès isteigimo, inicijuoto britų konservatoriu, UEN, ID ir ED likimas lieka neaiškus, nes dalis partijų, sudarančių šias grupes, išreiškè ketinimą jungtis prie naujosios grupès, kuri apims tautiškuosius konservatorius ir euroskeptikus. Todèl kyla klausimas, ar ankstesnès grupès išlaikys pakankamą narių skaičiu (7 valstybes ir 25 narius), kad toliau funkcionuotu.

${ }^{10}$ Hix, S., Marsh, M. Punishment or Protest? Understanding European Parliament Elections - http:// sitemason.vanderbilt.edu/files/b4Neq4/Hix.pdf (žiūrèta 2009 m. birželio 22 d.); Marsh, M. Vote Switching in European Parliament Elections: Evidence from June 2004: Paper presented in the second meeting of EES group, 12-13 May, 2006 - http://www.ees-homepage.net/papers/lisbon/marsh.pdf (žiūrèta $2009 \mathrm{~m}$. birželio 25 d.).

11 European Parliament, Professor Farrell: "The EP is now one of the most powerful legislatures in the world", 2007-06-18 - http://www.europarl.europa.eu/sides/getDoc.do?language=EN\&type=IMPRESS\&reference=20070615IPR07837 
2 lentelè. Politinès grupès Europos Parlamente

\begin{tabular}{|c|c|c|c|c|}
\hline Politinė grupè & $\begin{array}{l}\text { Lietuvos parti- } \\
\text { jos narès }\end{array}$ & $\begin{array}{l}\text { Narių iš Lietu- } \\
\text { vos } 2004 \mathrm{~m} .\end{array}$ & \begin{tabular}{|l} 
Narių iš Lie- \\
tuvos 2009 m. \\
(numatoma)
\end{tabular} & Politinė orientacija \\
\hline $\begin{array}{l}\text { Europos liaudies parti- } \\
\text { ja-Europos demokratai } \\
\text { (EPP-ED) }\end{array}$ & TS-LKD & 2 & $4-5$ & $\begin{array}{l}\text { EPP - proeuropietiški } \\
\text { krikšcionys demokratai; } \\
\text { ED-konservatoriai }\end{array}$ \\
\hline $\begin{array}{l}\text { Europos socialistu partija } \\
\text { (PES) }\end{array}$ & LSDP & 2 & 3 & $\begin{array}{l}\text { Proeuropietiški socialde- } \\
\text { mokratai ir socialistai }\end{array}$ \\
\hline $\begin{array}{l}\text { Liberalų ir demokratų al- } \\
\text { jansas Europai (ALDE) }\end{array}$ & DP, LiCS, LS & 7 & 2 & $\begin{array}{l}\text { Proeuropietišku partiju } \\
\text { spektras nuo konservato- } \\
\text { rių iki socialliberalų }\end{array}$ \\
\hline $\begin{array}{l}\text { Sajunga už tautų Europą } \\
\text { (UEN) (gali nelikti nuo } \\
2009 \text { m.) }\end{array}$ & TiT, LVLS & 2 & $0-3$ & $\begin{array}{l}\text { Nacionalkonservatoriai, } \\
\text { pasisakantys prieš ES } \\
\text { funkciju plètrą kultūros } \\
\text { srityje, tradicionalizmą }\end{array}$ \\
\hline $\begin{array}{l}\text { Europos žalieji - Euro- } \\
\text { pos laisvasis aljansas } \\
\text { (G-EFA) }\end{array}$ & - & - & - & $\begin{array}{l}\text { Žalieji ir regionalistai } \\
\text { (Europos laisvasis al- } \\
\text { jansas) }\end{array}$ \\
\hline $\begin{array}{l}\text { Europos jungtinè kai- } \\
\text { rè-Šiaurès žalieji kairieji } \\
\text { (GUE-NGL) }\end{array}$ & - & - & - & $\begin{array}{l}\text { Komunistai ir Švedijos } \\
\text { kairieji }\end{array}$ \\
\hline $\begin{array}{l}\text { Nepriklausomybe ir } \\
\text { demokratija (ID) (gali } \\
\text { nelikti nuo } 2009 \mathrm{~m} \text {.) }\end{array}$ & - - & - & - & $\begin{array}{l}\text { Euroskeptikai, pasisa- } \\
\text { kantys už ES funkciju } \\
\text { siaurinimą }\end{array}$ \\
\hline $\begin{array}{l}\text { Europos konservatoriai ir } \\
\text { reformistai (ECRG) }\end{array}$ & $\begin{array}{l}\text { Formuojasi } \\
\text { (gali būti TiT, } \\
\text { LLRA) }\end{array}$ & $\begin{array}{l}\text { Nebuvo, ikurta } \\
2009 \mathrm{~m} .\end{array}$ & $1-3$ & $\begin{array}{l}\text { Ketina suvienyti euro- } \\
\text { skeptikus ir nacional- } \\
\text { konservatorius, bet ne } \\
\text { nacionalistus }\end{array}$ \\
\hline
\end{tabular}

Lyginant išrinktųEP nariųpriklausymąEP grupėms matyti, kad jis dažniausiai atitinka ir partijos poziciją Lietuvoje. Po $2004 \mathrm{~m}$. EP rinkimų Lietuvos partijos išsiskirste i 4 grupes. TS-LKD įsijungè į didžiausią politinę grupę EP - Europos liaudies partiją - Europos demokratus. Joje turètų likti ir po EP rinkimų 2009 m. EPP-ED yra konservatyvi, proeuropietiška politinè grupè, vienijanti centro dešiniuosius, daugiausia - konservatyvios ir krikščioniškos demokratijos idèjų besilaikančias partijas. Iš esmès šios partijos pozicija nacionalineje politikoje atitinka ir TS-LKD poziciją $\mathrm{EP}^{12}$.

LSDP 2004-aisiais prisijungè prie Europos socialistų partijos grupės ir taip pat liks jos nare po 2009 m. EP rinkimų. PES vienija Europos socialdemokratines partijas. LSDP narių pozicija EP dažniau buvo artimesnè socialdemokratinèms idèjoms nei

${ }^{12}$ Autoriaus duomenys ịvertinti pagal balsavimą atskirais klausimais, kurie gali padèti nustatyti partijos nuostatų (žr. 2 išnašą) atitiktį Seime ir Europos Parlamente. 
LSDP pozicija nacionalinejje politikoje. Nepaisant to, kad LSDP narių nuostatos yra gana stipriai išsibarsčiusios politinėje skalëje (kaip kontrastas kitoms partijoms, kurių lyderiai dažniausiai yra konservatyvių arba populistinių pažiūrų ${ }^{13}$ ) ir partija artimesné PES savo pavadinimu, bet ne politika, vis dèlto Lietuvos socialdemokratai geba gana nuosekliai remti EP socialistų pozicijas.

Daugiausia vietu $2004 \mathrm{~m}$. laimëjusi DP po rinkimų buvo priimta į Liberalų ir demokratu aljanso Europai grupę. Nacionalinejje politikoje DP veikia kaip konservatyvi politinè jèga, todèl ji sustiprino konservatyvuji ALDE sparna, nors dalis DP europarlamentarų pagal balsavimus atitiktų liberalų apibrèžimą. DP frakcija EP buvo labai nevienalyte ir ilgainiui subyrejo. Kartu su DP antrą kartą kandidatavo tik vienas iš 5 jos atstovų - Šarūnas Birutis, o likusieji įsijungè i kitu partijų gretas (Danute Budreikaite - i Krikščioniu konservatorių socialinę sajungą (toliau - KKSS), Ona Juknevičienè - $\mathrm{i}$ LCP) arba iš viso nedalyvavo rinkimuose.

I ALDE gretas taip pat įsijungè LiCS atstovai, kurie po partijos skilimo $2005 \mathrm{~m}$. toliau veikè kaip LS atstovai (Eugenijus Gentvilas) arba nepriklausomi veikejjai (Margarita Starkevičiūtè). Liberalų pozicija labiau atitiko ALDE liberaliojo sparno politika, nepaisant to, kad nacionalineje politikoje liberalai yra konservatyvesni nei EP. Tiek DP, tiek LS nariai ketina likti šioje grupeje ir po $2009 \mathrm{~m}$. EP rinkimų.

Ketvirtoji grupe, ¿ kurią įsijunge LVLS ir TiT atstovai - konservatyvi ir į nacionalizmą linkusi Sajunga „Už tautų Europą“. Šių politinių partijų pozicija nacionalinèje politikoje iš esmès sutampa su grupès pozicija Europos Parlamente.

2009 m. euroskeptiškai nusiteikusi Jungtinès Karalystès Konservatorių partija išstojo iš EPP-ED ir èmèsi burti konservatyvią ir euroskeptišką grupę būsimajame EP. Kadangi dalis UEN nariu ir Nepriklausomybės ir demokratijos grupès narių svarsto galimybę jungtis prie naujosios grupès, dabar veikiančioms euroskeptinėms ir nacionalistinėms grupèms kyla pavojus nuo naujos EP kadencijos pradžios nebeatitikti naujų reikalavimu, keliamų grupių formavimui. Dabar grupei reikalingų valstybių skaičius yra padidintas nuo 6 iki 7 (iš dalies siekiant riboti nacionalistinių ir radikalių frakcijų kūrimąsi), o EP narių reikalaujamas minimumas - nuo 20 iki 25. Iš UEN pasitraukus Latvijos (jungsis prie Europos konservatoriu ir reformistu) ir Airijos (prisijungė prie ALDE) partijoms, grupè nebeatitinka šių reikalavimų. Tokios pačios problemos kyla ir ID grupei. Jei grupès nepritrauks naujų narių ir likviduosis, tikètina, kad TiT, kuri buvo įsijungusi į UEN, jungsis į ECRG. Prie pastarosios gali

${ }^{13}$ Autoriaus duomenys ịvertinti pagal politikų atsakymus ị puslapio „Mano balsas“ (www.manobalsas.lt) klausimus. Ivertinimui imti atsakymai į klausimus apie progresinio mokesčio įvedimą (6 klausimas), privatizavimą transporto sektoriuje (10 klausimas), pelno mokesčio tarifo mažinimą (11 klausimas), požiūrị i aukštojo mokslo reformą (2 klausimas). Šie atsakymai turetų padèti nustatyti respondento vietą socioekonominès politikos skalèje. Respondento vietos nustatymui kultūrinès politikos skalèje imti klausimai apie vienos lyties santuokas (15 klausimas), abortų draudimą (16 klausimas), tradicinès šeimos skatinimą (17 klausimas), dėmesị patriotiniam ugdymui (21 klausimas). Lyderiais šiuo atveju laikomi partijų nariai, kurie yra Seimo nariais. 
šlietis ir LLRA, kuriai ši grupè gali būti artima pagal pažiūras. Kita vertus, LLRA atstovas gali šlietis ir prie EPP-ED.

Žaliujų frakcijos, tikètina, nesugebės pritraukti Lietuvos atstovų, nes mūsų šalyje nèra žaliujų partijų.

Po 2009 m. EP rinkimu pakito Lietuvos atstovų sudètis. Pastebètina, kad 2009 m. EP rinkimai, priešingai nei $2004 \mathrm{~m}$., pasižymèjo ir iji pretenduojančių politinių partijų lyderiųgausa. Tai paaiškinama lyderių politinėmis ir teisinėmis problemomis Lietuvoje ir siekiu jas išspręsti per EP rinkimus. İEP buvo išrinkti DP lyderis Viktoras Uspaskichas, TiT lyderis Rolandas Paksas ir LLRA lyderis Valdemaras Tomaševskis.

2009 m. perrinkti 3 (25 proc.) europarlamentarai - Vytautas Landsbergis, Laima Andrikienè ir Justas Vincas Paleckis ${ }^{14}$. Pastebètina, kad nè vienas iš jų praejjusios kadencijos metu nekeitè partinès priklausomybès. Kiti buvę EP nariai arba pasirinko i EP nepatekusias partijas (Eugenijus Maldeikis ir Margarita Starkevičiūtė - PDP, D. Budreikaitè - KKSS, O. Juknevičienè - LCP), arba buvo nustelbti politinių partijų lyderiu, dalyvavusiu rinkimuose.

Net 50 proc. EP narių iš Lietuvos pakeite partinę priklausomybę kadencijos metu (daugiausia DP ir LiCS atstovai), iš jų 1/3 dalyvavo $2009 \mathrm{~m}$. EP rinkimuose kaip kitų partijų kandidatai. Šie duomenys rodo, kad politinès partijos negali būti tikros, jog pagal jų sąrašus išrinkti EP nariai liks atstovauti partijai. Be to, tai liudija silpną europarlamentarų ir nacionalinès valdžios ryšsi, nes tapus EP nariu, ilgainiui bendradarbiavimas su partija nutrūksta. Tokia situacija neskatina dalyvavimo EP rinkimuose.

Kalbant apie EP grupes derètu pastebėti, kad narystė EP grupèse yra stabilesnè nei atstovų naryste jas delegavusiose partijose, nes net ir pasitraukus iš partijos, iš EP grupès nepasitraukiama.

Po 2009 m. rinkimų tikètina, kad Lietuvos partinès frakcijos EP bus pastovesnès, nes išrinkti partijų lyderiai (3 iš 12 ) ir partijų kurių nariai neturètų keisti partinès priklausomybès (LSDP, TS-LKD, TiT), atstovai. Liberalų sajūdžio sąraše buvusio L. Donskio likimas ALDE frakcijoje taip pat neturètų kelti abejoniu. Vadinasi, dèl išrinktų kandidatu pažiūrų panašumo frakcijos subyrejjimas, kaip tai atsitiko su DP, yra mažai tikètinas.

\section{Išvados}

1. EP rinkimų rezultatai Lietuvoje vertintini pagal klasikinį antraeilių rinkimų, kuriems natūraliai būdingas pasyvus rinkèjų dalyvavimas, apibrèžimą. Atsižvelgiant i gautus duomenis galima teigti, kad negausus dalyvavimas rodo tiek menką rūpinimąsi ES reikalais, tiek pasitenkinimą Lietuvos buvimu ES (euroskeptinès partijos, pasisakančios prieš ES, rinkimuose pasirodè prastai). Be to, tai patvirtina

${ }^{14}$ Palyginimui: $2008 \mathrm{~m}$. Seimo rinkimuose buvo vèl išrinkta per 50 proc. Seimo narių. 
iškeltą rinkimu i EP antraeiliškumą hipotezę. Pažymètina, kad panašus rinkèjų aktyvumas buvo ir referendumo dèl Lietuvos stojimo į ES pirmają dieną, todèl tai negali būti laikoma euroskeptiškumo išraiška.

2. Rinkimų rezultatai rodo, kad Lietuvoje didejja politinè poliarizacija, nyksta partijos, turinčios dideli koalicini potencialą. Tai gali turèti neigiamos itakos ateityje formuojant panašios politinès orientacijos valdančiąsias koalicijas. Be to, ryškejja lyderystės krizè, ypač mažesnèse partijose, kurios lyderius arba ,pasiskolina“" (pvz., L. Donski), arba ketina trauktis iš nacionalinès politikos.

3. Atsiskleidžia ir partijų institucionalizacijos svarba. Tokia išvada daroma todèl, kad rinkejjai buvo linkę ateiti ir pareikšti paramą TS-LKD, nepaisydami jos vykdomų griežtų taupymo priemonių. Ypač ryški partijos institucionalizacijos svarba LLRA atveju.

4. Lietuvos politinių partijų pastovumas Europos Parlamente turètų didèti, nes i ji daugiau nei 2004-aisiais išrinkta partijoms issipareigojusių asmenų. Tikètina, kad Lietuvos partijų narystė EP grupèse nesikeis, išskyrus TiT, kuri gali prisijungti prie ECRG. 


\title{
THE FORECAST AND SITUATION OF EUROPEAN PARLIAMENT ELECTION IN LITHUANIA'2009
}

\author{
Mindaugas KLUONIS
}

\section{Summary}

Keywords: European Parliament, second-order elections, euro-scepticism, party system, political polarization, party institutionalisation.

The purpose of the article is to deliver the analysis of results of European Parliament election 2009 by examining three questions. Each question is examined in separate part of the article. The low participation in the election is discussed in the first part, the trends of party system development extrapolated from the results of elections in the second and ideological match of Lithuanian political parties with the ideology of groups in European Parliament, which members they are in the third one.

The article draws its conclusions by using theoretical framework (provided by Michael Marsh) on participation in election to European Parliament. The original research of the author is used as well. The article concludes that the results of the election to European Parliament 2009 reveals the trend of growing political polarization, but denies the notion, that low participation means sceptical attitude to the European Union among Lithuanian voters. Rather the elections fit in the classical second-order national contest category, which explains low participation. 